\title{
Information Literacy Competencies: A Conceptual Analysis
}

\author{
Dr. Chinwe Anunobi ${ }^{1}$ \& Obiora Kingsley Udem ${ }^{2}$ \\ Federal University of Technology, Owerri, \\ Imo State, Nigeria ${ }^{1}$, Department of Library and Information Science, \\ Nnamdi Azikiwe University Awka,Anambra State, Nigeria ${ }^{2}$ \\ chiinobis@yahoo.com ${ }^{1} \&$ obioraudem@yahoo.com ${ }^{2}$
}

\begin{abstract}
Purpose: This paper reviewed literature as they relate to Information Literacy Competency. The review is necessary so as to guide students as well as scholars of Library and Information Science who may want to be exposed to the concepts and elements of Information Literacy.

Design/Methodology: The exploratory approach was used for this study; first a conceptual framework was examined so as to identify the components of Information Literacy Competency which is combination of Knowledge, Skills and Attitude. This was followed by review of elements of three models of Information Literacy as well as review of views of scholars on Information Literacy Competencies. Finally position was taken on Information Literacy Competency.

Findings: The paper found out that the term Information Literacy Competency and Information Literacy skills though often used interchangeably are not the same. Information literacy competency is a combination of knowledge, skills and attitudes towards recognizing when and why information is needed, where to find it, how to evaluate, manage and apply it, synthesize, use and communicate it ethically and legally. On the other hand, skill is a component of competency which includes other components (knowledge and attitude).

Originality/Value: The value of this paper lies in its identification and discussion on review of the views and position on the concepts of information competency and literacy. It also brings together scholars and schools of thought ideology on information literacy competency which is expected to aid those in quest for knowledge.
\end{abstract}

Keywords: Information, Information Literacy, Competency, Information Literacy Competency

Paper Type: Conceptual

\section{Introduction}

The advancement in information and communication technologies (ICT) has created a revolution in all spheres of knowledge. This revolution has become so obvious in information packaging and dissemination. This $21^{\text {st }}$ century is characterized by information explosion and as a result, individuals are faced with diverse, abundant information choices in their academic environment, workplace, and personal lives. As more information is available in diverse forms, information stakeholders need the knowledge and skills to enable them know how to find, access, evaluate and effectively use information. Wilson (2001) opined that increasing attention to the need to find, access and effectively use information in recent years is partly the result of information overload, especially as it relates to the growth of digital information, which has even caused a new ailment termed "information fatigue syndrome". The idea of developing skills and knowledge to find, access and effectively use information, which evolved in the early 1970s has grown, taken shape and strengthened to become recognized as the critical literacy for the $21^{\text {st }}$ century (Bruce, 2002). Library and information science (LIS) professionals led the way in the early 1970s in conceptualizing this idea and its relationship to lifelong learning. As the environments of LIS professionals and academic libraries have changed, the abilities to find, access and effectively use information have also changed and broadened. What started as library orientation grew to be library instruction and bibliographic instruction and finally became information literacy. Information literacy according to Chartered Institute of Library and Information professionals (CILIP, 2004) can be defined as the recognition of when and why one needs information, where to find it, and how to evaluate, use and communicate it in an ethical manner. European Communities (2007) noted 
that competency is a combination of knowledge, students are expected to be information providers and educators on graduation but they cannot play this role effectively without, acquiring information literacy competencies through their university education. As a result, LIS curriculum is developed in such a way that LIS students should graduate as information literates. They are expected to possessed information literacy competencies which will enable them recognize when and why they need information, where to find it, how to evaluate, use and communicate information ethically and legally.

This paper will give a review of literature as they relate to information literacy competency. The review is necessary so as to guide students as well as scholars of library and information science who may want to be exposed to the concepts and elements of information literacy. The paper will carry out review that will bother on the concept of information and information literacy as well as information literacy competencies. It will review the elements of the three models of information literacy. It will also review pool of views of scholars on information literacy competencies. It will finally take position on information literacy competencies.

\section{Concept of Information}

The term information despite its wide usage is not devoid of definitional controversy, from its more general and widely used context in which it evoked communication (Owusu-Ansah, 2003). The universally accepted definition of information as observed by Omekwu (2003) may still be debatable. No wonder researchers like Loose (1997), and Aina (2004) observed that various individuals and professions used the term to proffer different meanings.

The term information according to Loose (as cited in Owusu-Ansah, 2003) is used differently by individuals in different walks of life, from specialists working in information based professions, such as communication media and information management, those in the computing and cognitive science, as well as by people involved in less scholarly pursuits. Aina (2004) noted that the term information is difficult to define because it has several dimensions. To some people, information is news, while others refer to information as facts, and yet to others, it is essentially data. While telecommunications engineers associate skills and attitude appropriate to a context. LIS information with bits and data, librarians associate information with recorded knowledge, and the microbiologist consider information as genes in DNA, which is transmitted from one generation to the other.

Buckland (as cited in Aina, 2004) discussed the ambiguities nature of information when he posted information as:

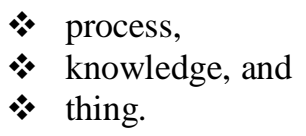

Information is a process when it is performing the function of informing, which involves transmitting information from a source to a recipient. It is knowledge when it is performing the role of imparting knowledge to an individual, where it reduces uncertainty under both circumstances. Information is intangible, and it becomes tangible when it is a thing such as a physical object like data or document. In this regard, Zin (2007) classified information into three groups:

* Anything perceived as potentially signifying something (for example, printed books),

* The process of informing, and

* That which is learned from some evidence or communication.

In an attempt to provide universally accepted definition of information, Ojedokun (2007) opined that information is statements of facts, figures, ideas and creative works of the human intellect, which are logically or by way of reasoning interrelated, and have been communicated formally or informally in any formats. In this regards, Norman (as cited in Owusu-Ansah, 2003) defined information as factual data, ideas, and other knowledge emanating from any society that are identified as being of value, sometimes gathered on a regular basis, organized in some fashion, transmitted to others, and used in some meaningful way. This Norman definition of information according to Owusu-Ansah, (2003) best summarized as well as stated the central interpretation of the term information in a manner most applicable to the librarian's use and yet remained accommodating of usages in other fields.

From the above views of different scholars, it can be seen that despite the fact that there is no generally accepted definition of information, it is apparent that there is a connection between data,

Journal of Applied Information Science and Technology, 7 (2) (2014) 
information and knowledge. Data are raw evidence, unprocessed, eligible to be processed, to produce information; knowledge is process of becoming informed, it is dependent on information which is processed data. Information perceived becomes knowledge (Smiraghia as cited in Zinc, 2007). The term information from the aforementioned can be seen as any communication or representation of knowledge such as facts, data or opinions in any form that is meaningful to the recipients. That is, information is data that has been processed into a form that is meaningful to the recipient.

\section{Concept of Information literacy}

Information literacy concept across the globe evolved from precursors such as library instruction, bibliographic instruction and user /reader education (Chevillotte, 2007; Fidzani, 2007; Fjallbrant, 2000; Homann, 2001; Lau, 2006; Pinto \& Sales, 2006; Tolonen, 2006; Mittermeyer \& Quirion, 2003; Sinikara \& Jarvelainen, 2003; Virkus, 2003 and Neely, 2002). The information-literacy movement in European countries, similar to other countries, as recorded by Virkus, (2003) evolved from precursors such as library instruction, bibliographic instruction and user/reader education. Virkus further note that the majority of information literacy initiatives and programmes in Europe have been initiated in recent years; academic librarians in Europe have been involved in user education for many years. During the 1970s and 1980s, many academic libraries in the United Kingdom, Germany and Scandinavia started fairly ambitious programmes of user education, bibliographic instruction, or reader education and they have provided user education in the form of one or more of the following: short orientation courses in the use of the library, its information resources and catalogues for new students, and courses in information literacy for undergraduate and/or for postgraduate students. Many scholars are of the view that movement of information literacy in African countries is similar to that of European countries as well as other countries. Fidzanic, (2006) is of the view that the concept of information literacy in African countries in the 80 's started with development of user education programmes which covered library orientation and bibliographic instruction to new students. Owusu-Ansah, (2003) opined that the concept of information literacy follows the same trend in Nigeria.
The Middle States Commission on Higher Education (2003) in line with opinions of the other scholars opined that the term information literacy has evolved over the past two decades in response to the changing requirements of higher education. From its beginnings as a form of library instruction, the concept now has been extended to describe a more comprehensive vision of teaching and learning in the academic world. Shenton (2009) concluded that:

Information literacy has certainly
expanded greatly in scope from its
antecedents as user education or
bibliographic instruction, which
emphasized the exploitation of library
tools, such as indexes, catalogues and
classification schemes, and the use of
particular types of sources, to
expansive skills sets that are today
permeated by a more widely applicable
problem-solving perspective (p. 226).

The unanimous views of different scholars on concept of information literacy shows that the term information literacy is not abstract or arbitrary but evolved from substance such as library instruction/library orientation, bibliographic instruction and user/reader education to fill an obvious vacuum in the world of information conception, acquisition and use for lifelong learning.

The term information literacy was first introduced in 1974 by Paul Zurkowski, former president of the United States Industry Association, in a paper prepared for the National Commission for Libraries and Information Science (NCLIS), in which he talked about the need for people to become information literate, if they were to survive and compete in an emerging information society (Grassian \& Kaplowitz, 2001; Horton, 2007; Kaushik \& Mishra, 2009; Mittermeyer \& Quirion, 2003). Zurkowski (as cited in Thomas, 2004) defined information literacy as "the ability to use techniques and skills for the wide range of information tools as well as primary sources in molding information solution to a problem". Association of College and Research Libraries(ACRL, 2000) in their attempt to provide universally accepted definition of information literacy, defined information literacy as a set of abilities requiring individuals to recognize when information is needed and have the ability to locate, evaluate, and use effectively the needed information. This definition and 
explanation given by ACRL according to Ranaweera, (2010); Bundy, (2004), is considered the foundation for the world wide concept of information literacy. Bundy (2004), in line with ACRL definition, refers to information literacy as the broad set of skills and understandings that enable a person to recognize information needs, decide which resources will best answer those needs, know how to use the resources effectively, and evaluate the information they found.

Further to that, Information Literacy Meeting of Experts (2003), looking at information literacy in the context of problem solving and information society stated that:

Information Literacy encompasses
knowledge of one's information
concerns and needs, and the ability to
identify, locate, evaluate, organize and
effectively create, use and communicate
information to address issues or
problems at hand; it is a prerequisite for
participating effectively in the
Information Society, and is part of the
basic human right of lifelong learning
(p. 1$)$.

Information literacy according to Johnston and Webber (2003) is the "adoption of appropriate information behaviour to obtain, through whatever channel or medium, information well fitted to information needs, together with critical awareness of the importance of wise and ethical use of information in society". Webber (2006) expanded on the definition by acknowledging that:

* "Appropriate information behavior" means that information literate person is aware of what his/her information habits are and is able to adapt his/her information behavior depending on the nature of the information need.

* "Whatever channels or medium" acknowledges that people need many different kinds of information. For example, people are sometimes a good source of information, books may be best in order circumstance, numeric data may sometimes be appropriate.

- "Wise and ethical use of information society" means that information literate people are aware of the way in which information may be culturally sensitive, or politically meaningful.
On this regard, the Chartered Institute of Library and Information professionals (CILIP, 2004) defined information literacy as recognition of when and why you need information, where to find it, and how to evaluate, use and communicate it in an ethical manner. The Middle States Commission on Higher Education, in the 2002 edition of Characteristics of Excellence in Higher Education: Eligibility Requirements and Standards for Accreditation define information literacy as:
An intellectual framework for identifying, finding, understanding, evaluating and using information. It includes determining the nature and extent of needed information; accessing information effectively and efficiently; evaluating critically information and its sources; incorporating selected information in the learner's knowledge base and value system; using information effectively to accomplish a specific purpose; understanding the economic, legal and social issues surrounding the use of information and information technology; and observing laws, regulations, and institutional policies related to the access and use of information (The Middle States Commission on Higher Education, 2003. p. 1).

American Library Association (ALA, 1989) that was regarded as the first group to define who is an information literate individual, stated that "to be information literate, a person must be able to recognize when information is needed and have the ability to access, evaluate and use effectively the needed information". Other definitions of the information literate person tend to cover the same elements, but expand on them in one way or another. For example, Council of Australian University Librarians, (2001) stated that an information literate person is the one who is able to: recognize a need for information; determine the extent of information needed; access the needed information efficiently; evaluate the information and its sources; incorporate selected information into their knowledge base; use information effectively to accomplish a purpose; understand economic, legal, social and cultural issues in the use of information; access and use information ethically and legally; classify, store, manipulate and redraft information collected or 
generated; and recognize information literacy as a prerequisite for lifelong learning. Virkus, Boekhorst, Gomez-Hernandez, Skov and Webber, (2006) also noted that an information literate student of library and Information Science student should:

* Be able to recognize when he/she needs information, to identify the nature of the information need, and what the gap is between what he/she knows and what he/she needs.

* Be aware of what different channels and sources are available, be able to identify the appropriate resources for a particular information need, and use these resources effectively to acquire the needed information.

* Be able to evaluate information effectively.

* Be able to manage and apply information.

* Be able to synthesize information and use it to create new knowledge and understanding.

* Be aware of the cultural, ethical, economic, legal, and social issues surrounding the use of information.

The attribute of information literacy according to Andretta, Hernon \& Dungan (as cited in King, 2007) belongs in three groups, the first being information skill, that is, to employ traditional and modern information technology to retrieve, manage and present information in an ever widening array of information sources. The second is being the cognitive skills of analyzing, problem solving, critically thinking, critically evaluating, synthesizing, organizing and communicating information. The third is embanked in the values and beliefs resulting in using information wisely and ethically as well as with social responsibility and community participation.

Boekhorst (2003) summarised the definitions and description which have been presented over many years into three concepts:

* The Information Communication and Technology (ICT) concepts: the information literacy refers to the competence to use ICT to retrieve and disseminate information

* The information (re)sources concept: information literacy refers to the competence to find and use information independently or with the aid of intermediaries.

* The information process concept: this concept includes both the ICT and the information and the information (re)sources concept and persons are considered as information systems that retrieve, evaluate process and disseminate information to make decisions to survive for self actualization and development.

The above explanation of information literacy concept from different schools of thought shows that that information literacy cannot be understood in standalone terms. Webb and Powis (2005), for example, discussed the area from the perspective of learning styles while Eisenberg, Lowe and Spitzer (2004) make connections in relation to information literacy, digital literacy and network literacy. Boekhorst (as cited in Virkus, Boekhorst, Gome Hernandez, skov \& Webber, 2005) stated that:

all these literacies (basic literacy,
scientific literacy, technological
literacy, visual literacy, cultural
literacy) can be considered as specific
competences that belong under the
information literacy umbrella. Therefore
information literacy should be
considered as a container concept,
which refers to competencies of people
to recognize the need for information
and to satisfy their information needs
for survival, self-actualisation and
development (p. 66).

Montgomery (as cited in Thomas, 2004), expanded on this theme by acknowledging that " information literacy has become an umbrella term encompassing electronic searching and information retrieval skills, library skills, media skills, research skills, reference skills". Eisenberg and Berkowitz, (as cited in Langfford, 1998) stated that information literacy is not library skills, nor is it computer skills, nor even information problem solving skills, but all of these are necessary enhancers of information literacy. Audunson and Nordlie, (as cited in Virkus, 2003) also highlighted three main categories of information literacy as; technical capabilities (also known as computer literacy); intellectual capabilities related to traditional literacy; and communicative competency that presupposes technical as well as intellectual capabilities and at the same time transcends 
them. Ferguson (2003) opined that a complete picture of information literacy must include five essential components; basic literacy, library literacy, media literacy, technology literacy and visual literacy. On this regard, the Standing Conference of National and University Libraries, (SCOUNL, 2011) concluded that "information literacy is an umbrella term which encompasses concepts such as digital, visual and media literacy, academic literacy, information handling, information skills, data curation and data management".

From the foregoing discussion, it can be synthesized that information literacy which evolved from precursors such as library orientation, library instruction, bibliographic instruction and user/reader education deals with recognition of when and why information is needed, where to find it, and how to access and evaluate, use and communicate it in an ethical manner. It is an umbrella term which encompasses concepts such as computer literacy, technology literacy, digital literacy, library literacy, visual and media literacy, academic literacy, information handling, information skills, and data management.

\section{Concept of Competency}

Competency is a term that is used both scientifically and in everyday language. Competency according to Organization for Economic Co-operation and Development (OECD, 1999) can be "attributed to individuals, social groups or institutions, when they possess or acquire the conditions for achieving specific developmental goals and meeting important demands presented by the external environment". Higher institutions especially university must educate, teach and prepare each student for lifelong learning, as a result, the review of the concept of competency in this particular study will focus on individual attribute of competency rather than the competence of a social group or institution.

As indicated by Alberta Education (2010), there are many definitions used worldwide to define the term competency. OECD (1999) listed a descriptive list of nine different ways in which competency has been defined, described or interpreted theoretically. The list includes competency as: general cognitive ability; specialized cognitive skills; competenceperformance model; modified competenceperformance model; motivated action tendencies; action competence; key competencies; and meta-competencies.

OECD is of the view that a key competency is central competency:

* Upon which (many) others depend;

* Which facilitates understanding and learning a variety of different concepts, rules, principles, strategies, and skills; and

* Which could be applied to solve different problems in different situational contexts.

Key competency according to European Commission, (2004) represents a transferable, multifunctional package of knowledge, skills and attitudes that all individuals need for personal fulfillment and development, inclusion and employment which should have been developed by the end of compulsory schooling or training, and should act as a foundation for further learning as part of lifelong learning.

According to European Communities (2007), competency can be defined as a combination of knowledge, skills and attitudes appropriate to the context. On this regard, Albert Education (2011) defined competency as an interrelated set of attitudes, skills and knowledge which are drawn upon and applied to a particular context for successful learning. Albert Education further opined that the term competency and skills are often used interchangeably. As a broader concept, competency is not limited to cognitive elements (involving the use of theory, concept or tacit knowledge); it also encompasses functional aspects (involving technical skills) as well as interpersonal skills (example, social or organizational skills) and ethical values. A skill on the other hand, is ability to perform tasks and solve problems (European Centre for the Development of Vocational Training, 2008), and can be acquired in a matter of months while competencies are acquired over a number of years.

Virkus (2003) pointed out that "competency is the ability, within a certain professional or academic domain, to make use of already learnt as well as new knowledge and skills across traditional subject areas to adequately solve real - life, poorly defined problems". Anttiroiko, Lintila and Savolainen (2001) stated that competency has two dimensions; knowledge and skills: "Knowledge may be seen as

Journal of Applied Information Science and Technology, 7 (2) (2014) 
understanding of how everyday world is constituted and how it works. Skills involve the ability to pragmatically apply, consciously or even unconsciously, our knowledge in practical settings". OECD (2005) in contrast, stated that competency is more than just knowledge and skills. It involves the ability to meet complex demands, by drawing on the mobilizing psychosocial resources (including the skills and attitudes) in a particular context. For example, the ability to communicate effectively is competency that may draw on an individual's knowledge of language, practical information technology skills and attitudes towards those whom he or she is communicating.

From the foregoing discussion, one can infer that competency is a combination of knowledge, skills and attitudes appropriate to the context which are fundamental for each individual in knowledge based society. In other words, competency deals with an individual's demonstrated capacity to perform, that is, the possession of knowledge, skills, and attitudes needed to satisfy the special demands or requirements of a particular situation. Competency is developed over a time and demonstrated to a varying degree appropriate to the developmental age of learners and their learning needs.

\section{Concept of Information literacy competency}

Information literacy competency according to Wen and Shih, (2008) is "the possession of the necessary knowledge, skills, and attitudes (the recognitions of the value, functions and roles of information) to effectively apply information technology to collect, analyze, assess, organize and synthesize information for solving problems". Information literacy competency which is combination of information literacy and competency deals with a combination of knowledge, skills and attitudes towards recognizing when and why information is needed, where to find it, how to evaluate, manage and apply it, synthesize, use and communicate it ethically and legally.

Contrary, Catts and Lau (2008) looking at information literacy competencies in aspect of knowledge and skill alone stated that competencies in information literacy is the capacity of people to recognize their information needs; locate and evaluate the quality of information; store and retrieve information; make effective and ethical use of information and apply information to create and communicate knowledge. University of Liverpool Teaching and Learning Committee (2007) in direction of information literacy skills alone defined information literacy competency as:

* the ability to articulate a need for information and identify a range of resources from which it might reasonable be meet;

* the ability to construct the strategies for locating information, including the identification of keywords and synonyms, constructing a search strategy using appropriate commands (for example, Boolean operators) and knowing how to broaden and narrow a search;

* the ability to locate and access information, including using the library catalogue, indexing services, citation services and databases, and using current awareness methods to keep up to date;

* the ability to compare and evaluate information obtained from different sources, including awareness of bias and authority issues and understanding of the peer review process of scholarly publishing; and

* the ability to organize bibliographic information and convey it to others, including constructing a personal bibliographic system, citing references appropriately and understanding issues of copyright and plagiarism.

Furthermore, Jacobs, Rosenfeld and Haber (2003), posited that information literacy competency includes an understanding of the architecture of information and the scholarly process; the ability to navigate among a variety of print and electronic tools to effectively access, search and critically evaluate appropriate resources; synthesize accumulated information into an existing body of knowledge; communicate research results clearly and effectively; and appreciate the social issues and ethical concerns related to the provision, dissemination, and sharing of information.

From the foregoing discussion, it is evident that many authors tends to undermine attitude as a component of competency thereby looking at only knowledge and skills, yet some others sees competency as skills alone. But this present 
review sees information literacy competency as possession of the necessary knowledge, skills, and attitudes (the recognitions of the value, functions and roles of information) to recognize the need for information; recognize that accurate and complete information is the basis for intelligent decision making; identify potential sources of information; develop successful search strategies; access sources of information, including computer-based and other technologies; evaluate information; organize information for practical application; integrate new information into an existing body of knowledge; use information in critical thinking and problem solving; understanding many of the economic, legal, and social issues surrounding the use of information and accesses and uses information ethically and legally. In other words, information literacy competency has to do with knowledge on when and why information is needed, where to find and access it, how to evaluate, synthesize, use and communicate it ethically and legally; skills on how to determine the extent of information needed, how to access it, critically evaluate the needed information and its sources, synthesize, use and communicate it ethically and legally; and attitude towards acquisition of these competencies.

\section{Models of information literacy}

Information scientists have propounded different theoretical models to explain the necessary competencies expected from information literate individual. This paper will review elements of three models of information literacy. These three models are:

* SCONUL's Seven Pillars of Information Literacy model;

* Big Six information literacy skill model; and

* Doyle's attribute of information literate person.

\section{SCONUL's seven Pillars of Information Literacy model}

The United Kingdom's Society of College, National and University Libraries (SCONUL) published its information literacy model called the Seven Pillars of Information Literacy in 1999. This model according to (Webber, 2006), have been widely used in the United Kingdom and around the world. However, in 2011 the SCONUL working Group on Information Literacy updated and expanded the model in order to reflect more clearly the range of different terminologies and concepts which are now understood as information literacy. Information literate researchers according to SCONUL (2011) will demonstrate an awareness of how they gather, use, manage, synthesize and create information and data in an ethical manner and will have the information skills to do so effectively. In other words, this new model defines the core competencies which include knowledge, skills and attitude that are the goals of information literacy development in higher education, with each core competency called a "pillar". Within each "pillar" a researcher can develop from "novice" to "expert" as they progress through their research life, although, as the information world itself is constantly changing and developing, it is possible to move down a pillar as well as progress up it. The pillars are envisioned as a circle or cycle, rather than a sequence, and individuals can achieve different levels of complexity within each pillar.

The seven pillars are:

* Identify: A researcher is able to identify a need for information

* Scope: A researcher can assess current knowledge and identify gaps

* Plan: A researcher can construct strategies for locating information and data

* Gather: A researcher can locate and access the information and data they need

* Evaluate: A researcher can review the research process and compare and evaluate information and data

* Manage: A researcher can organize information professionally and ethically

* Present: A researcher can apply the knowledge gained: presenting the results of their research, synthesizing new and old information and data to create new knowledge and disseminating it in a variety of ways. 


\section{F $S 0$ N U L Seven Pillars of Information Literacy}

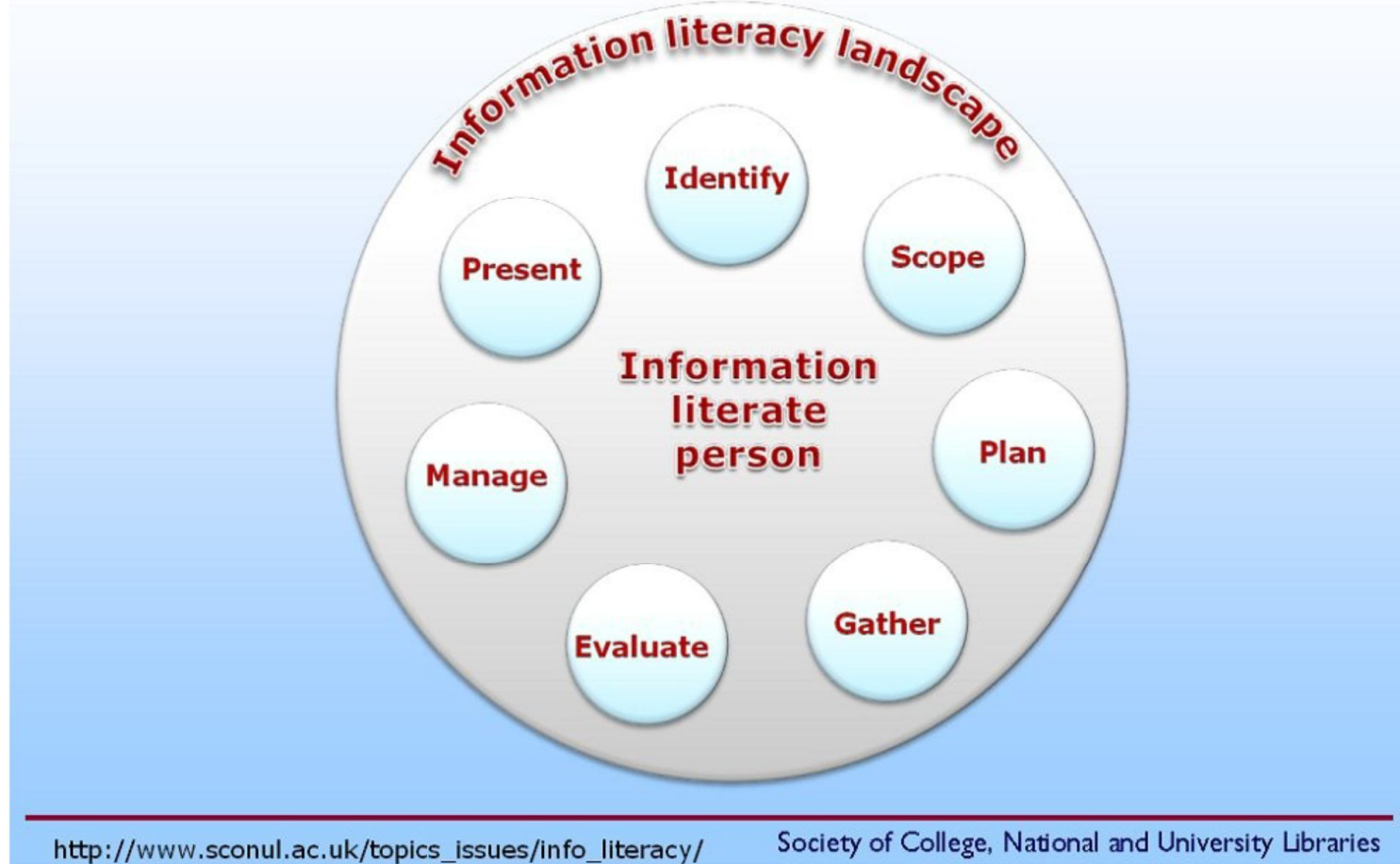

Each pillar according to SCONUL (2011) is further described by a series of statements relating to a set of competencies. In other words, each pillar deals with combination of knowledge, skills and attitude towards identifying a need for information; assessing current knowledge and identifying gaps; constructing strategies for locating information and data; locating and accessing the information and data needed; reviewing the research process and comparing and evaluating information and data; and organizing information professionally and ethically.

This theoretical model of information literacy by SCONUL (2011) is very necessary in teaching information literacy because it explained what are expected from individuals in order to attain the information literacy competencies. In other words, they deal with attributes of information literate person which is the combination of knowledge, skills and attitude that make up information literacy competencies.

\section{Big six information literacy skill model}

Big Six information literacy model which deals with information literacy knowledge and skills was propounded by Eisenberg and Berkowitz (1990). Big Six information literacy model according to Thomas (2004) is "an instructional model currently being used by thousands of library media specialists in school districts across North America and around the world". Information literacy in this model according to Bruce (2004) may be described as systematic information behaviour.

In effect, the model calls for application of six step strategy that requires students to define the task that has been set before them and the expectations in terms of the quantity and quality of the product they will produce; select strategies and resources for finding the information they are going to need; locate and access relevant and appropriate information resources; use the information by engaging or extracting it through reading, note taking, and highlighting and by determining its relevancy for the task; synthesize the information in making a decision or creating a project, writing a paper or producing a performance or exhibition; and evaluating the process and the project in terms of its effectiveness. In other words, Eisenberg and Berkowitz Big Six (as cited in Ojedokun, 2011) steps are: 
* Task Definition: (determining the purpose and need for information)

$\circ$ Define the problem.

- Define the information requirements of the problem.

* Information Seeking Strategies: (examining alternative approaches to acquiring the appropriate information to meet defined needs)

- Determine the range of possible resources.

- Evaluate the different possible resources to determine priorities.

* Location and Access: (locating information sources and information within sources)

- Locate sources (intellectually and physically).

- Find information within resources.

* Use of Information: (using a source to gain information)

$\circ$ Engage (e.g., read, hear, view) the information in a source.

- Extract information from a source.

* Synthesis: (integrating information drawn from a range of sources)

○ Organize information from multiple sources.

○ Present information.

* Evaluation: (making judgments based on a set of criteria)

○ Judge the product (effectiveness).

○ Judge the information problemsolving process (efficiency).

Essentially, Thomas (2004) noted that the big Six skills approach ties cognitive levels (Bloom, 1956) to various stages of the information process by identifying needs (knowledge level); relating the resources to the aspects of the problem (comprehensive level); selecting channels and sources (application level); identifying salient elements within and across information sources (analysis level); restructuring and communicating information (synthesis level); and making judgments about the information obtained in relation to specific needs (evaluation level).
Learning to be information literate involves practicing the use of the system, or the steps, when engaged in learning tasks. Eisenberg and Berkowitz Big Six information literacy model is important because they tried to explain the processes an individual has to undergo in order to attain the competencies needed to become information literate. This process involves attribute of information literate person which LIS postgraduate students are expected to possess in order to attain the information literacy competencies.

\section{Doyle's attribute of information literate person}

Doyles' (1992) attributes of the information literate person are the outcome of a Delphi study, in which a group of experts discussed and agreed upon characteristics associated with information literacy. In this model, the information literate person is one who recognises that accurate and complete information is the basis for intelligent decision making, recognises the need for information, formulates questions based on information needs, identifies potential sources of information, develops successful search strategies, accesses sources of information, evaluates information, organizes information, integrates new information into an existing body of knowledge, and uses information in critical thinking and problem solving. Learning to be information literate according to Bruce (2003) involves acquiring and demonstrating these attributes. Doyles' theoretical model of information literacy is related to the present position since it deals with attributes of information literate persons which when combine with competency (knowledge, skills and attitude) will become information literacy competency.

The three theoretical models of information literacy as have written thus far are very fundamental in teaching, learning and becoming information literate. They explained in details what are expected from students or individuals in order to attain the information literacy competencies. In other words, they deal with attributes of information literate person which is the combination of knowledge, skills and attitude that make up information literacy competencies. Though the models were not discussed in line with information literacy knowledge, skills and attitude, however critical analysis reveals evidence of attribute of 
information literate persons which combine knowledge, skills and attitude all together.

\section{Views of scholars on information literacy competencies}

\section{Information literacy knowledge}

Town's (2002) presentation at the first international conference on information technology and information literacy in Glasgow, in an attempt to explain information literacy knowledge stated that "information literacy is knowledge rather than simple skill, achieved by education rather than training, created through partnership between professionals and is a lifelong endeavour that is contextual in field and service access". Information literacy knowledge as pointed out by Horton (2007) can be grouped into eleven (11) stages or life cycle. The eleven stages of information literacy knowledge according to Horton include: Stage one; realize that a need or problem exists that requires information and its satisfactory resolution. Stage two; know how to accurately identify and define the information needed to meet the need, solve the problem, or make the decision. Stage three; know how to determine whether the needed information exists or not, and if it does not, know how to create, or cause to be created the unavailable information (also referred to as "creating new knowledge"). Stage four: know how to find the needed information if you have determined that it does, indeed, exist. Stage five; know how to create, or cause to be created, unavailable information that you need; sometimes called "creating new knowledge." Stage six; know how to fully understand found information, or know where to go for help if needed to understand it. Stage seven; know how to organize, analyze, interpret and evaluate information, including source reliability. Stage eight; know how to communicate and present the information to others in appropriate and usable formats and mediums. Stage nine; know how to utilize the information to solve a problem, make a decision or meet a need. Stage ten; know how to preserve, store, reuse, record and archive information for future use. Stage eleven; know how to dispose of information no longer needed, and safeguard information that should be protected.

Newto (2005) in an attempt to define information literacy knowledge opined that information literacy has to do with knowing: when you have a need for information; the resources available to you; how to find information; the need to evaluate results; how to work with or exploit results; the ethics and responsibility of using information; how to communicate and share your research finding; and how to manage your research findings. The Middle States Commission on Higher Education (2003), in their attempt to outline information literacy knowledge expected from students, stated that an information literate student: always thinks about framing the research question so that it is appropriate for the breadth and depth required for the research project; asks questions for clarification after receiving an assignment; knows where to start looking for information, is aware of a broad range of information sources (e.g., electronic and print periodicals, chapters in books, government documents, archival material, and microfilm); conducts electronic database searches effectively (e.g., knows how to use quotation marks, Boolean operators such as or/and/not, and other technical strategies); knows how to evaluate information sources; is able to select key points from retrieved information and summarize them, rather than simply repeating material from research; evaluates and explains or resolves contradictory information; understands what plagiarism is and some of the complexities of copyright law, the ethical use of information, intellectual property, etc.; has learned how to cite material appropriately and develop a bibliography; is able to develop new insights or theories, or discover previously unknown facts, based on material he or she already knew and the new information; and recognizes that a set of specific information literacy skills is transferrable and can be applied throughout life, for both professional and personal learning objectives. Furthermore, the University of Calgary library (n.d) looking at information literacy knowledge stated that information literacy knowledge focuses on: recognization of the need for information; knowing how to access information; understanding how to evaluate information; knowing how to synthesize information; and knowing how to communicate information. Regha, Rani and Hariharan (2009) in their attempt to discuss information literacy knowledge framed information literacy into four dimensions which was in line with the Information literacy competency Standard for Higher education by Association of College Research Libraries. These dimensions include; need, locate, evaluate and use. Their elaboration of the dimensions include : 
Need; how students recognize their need for information? When a task, say an assignment or a presentation or a research study is given to a student, he/ she recognize that he/she is in need of particular information. The student is also to identify what is needed and also define the need. Here defining the need is to see the area, scope and applicability of information.

Locate; after identifying the information need, the

* Identifying the sources of information student has to be aware of various sources of information like primary and secondary sources and the ways to locate them

* Knowing the various forms of information - information is available in various formats like print, online, $\mathrm{CD}$ ROMs and so on

* Understanding the related concepts of information - to search for particular information, always one has to be aware of the related concepts to explore more relevant results

* Knowing how to formulate search strategies by using various search techniques like Boolean operators (AND, OR, NOT) and so on

* Understanding the need to possess library skills. Library skill is a skill which helps to locate a resource in the library by using a system of classification of resources

Evaluate; in the period of information explosion, information is available in abundance. Hence the students have to be educated to evaluate the collected information. The collected information can be evaluated based on

* Authenticity - it should be found out whether the collected information is authentic or not. It can be checked by author, publisher or the institution from whom the information came in.

* Accuracy - it can be checked to avoid certain bias and prejudice

* Up-to-date - it has to be ensured that the collected information is the current.

Use; after going through various dimensions of Information Literacy like Need, Locate, Evaluate, the collected information has to be used to satisfy the purpose for which the information was looked for. Using the information also includes reporting of the information in an appropriate way or medium and by abiding by legal and ethical considerations.

Hepworth (1999) stated that information literacy knowledge deals with understanding of how to: recognize that accurate and complete information (textual, numeric or graphical) is the basis for intelligent decision making; determine exactly what problem or aspect of the problem

studleinthawith umelerstardehodefonbocanel thdetemfnimeation. Locat what information is required for the task in terms of type of material, media and comprehensiveness; formulate questions based on information needs that help to define what content is required; identify potentially relevant and valuable primary, secondary and tertiary sources of information; develop successful search strategies in both the paper based and electronic domain for identifying secondary information; gather information and data through experiment or through secondary sources; organize and store information; interpret, analyze, synthesize, evaluate and also to critically challenge the validity of collected information; develop insights, judgments, and predictions; use effective and appropriate tools and methods for the presentation and visualization of data and findings; and adapt these cognitive and behavioural information 'strategies' to different situations and contexts.

From the foregoing discussion, though many of the authors did not mention information literacy knowledge in their work but a critical analysis of their position divulges that information literacy knowledge has to with the understanding of how to: recognize a need for information; determine the extent of information needed; access information efficiently; critically evaluate information and its sources; classify, store, manipulate and redraft information collected or generated; incorporate selected information into knowledge base; use information effectively to learn, create new knowledge, solve problems and make decisions; access and use information ethically and legally.

\section{Information literacy skills}

Information literacy skills according to Mitchell (n.d) are specific tasks or procedures which serve information need. Ranaweera (2008) opined that "information literacy skills empower the people with critical skills which will help them to become independent lifelong learners. These skills will enable people to apply their knowledge from familiar environment to the unfamiliar". Information literacy skills as 
pointed out by Kovalik, Jesen, Schloman and Tipton (2010) refers to an individual's ability to recognize when there is a need for information, and to be able to identify, locate, evaluate, and effectively use that information for the issue or problem at hand. Mitchell (n.d) indicated that Information literacy skills are exemplified by ideas such as the ability to discover, retrieve, and use information, the ability to manage information, and the ability to make critical choices about information resources. Ojedokun (2007) posited that information literacy skills in all disciples requires an individual to be able to define problem; initiate a plan to find information; locate and access resources; use the information; synthesize information; and carry out some forms of evaluation. On this regard, Bruce (2003) pointed out that information literacy skills deals with the ability to access, evaluate, organize and use information in order to learn, solve problem, and make decisions in formal and informal learning contexts, at work, at home and educational settings. Andretta (2005) study of information literacy skills identifies higher and lower order thinking associated with information literacy skills. Lower order thinking involves activities such as the identification of keywords, synonyms and related terms when a search strategy is formulated. Higher-order thinking at the other end of the scale involves abstraction to develop a new hypothesis.

Information literacy skills were summarized by Barry, (1997), DeMars, Cameron and Erwin (2003) and Eisenberg and Berkowitz (1995) into the following sequential stages:

* Define, formulate and analyse the task or problem;

* Describe services typically available in libraries;

* Choose appropriate reference sources for a particular information need;

* Employ an efficient search strategy for a research paper or speech;

* Search library catalogues, research data bases and the Internet effectively;

* Locate, access and extract relevant information in sources;

* Evaluate sources in terms of accuracy, authority, bias and relevance;

* Record and store collected information;

* Organize and synthesis information in the required format from multiple sources; and
* Apply information ethics by citing sources appropriately and observing copyright.

The International Federation of Library Associations and Institutions (IFLA) information literacy standards as noted by Lau (2006) grouped information literacy skills under three basic information literacy components which include; access, evaluate and use. The three basic information literacy components are further categorized with some features.

Access; the user accesses information effectively and efficiently; this covers the following: Defines or recognizes the need for information; decides to do something to find the information; expresses and defines the information need; initiates the search process; identifies, and evaluates potential sources of information; develops search strategies; accesses the selected information sources; and selects and retrieves the located information

Evaluation; the user evaluates information critically and competently; this focuses the following: Analyzes, and examines, extracting information; generalizes and interprets information; evaluates accuracy and relevance of the retrieved information Organization of information; arranges and categorizes information; groups and organizes the retrieved information; and determines which the best and most useful information is.

Use; the user applies/uses information accurately and creatively in the following ways: Finds new ways to communicate, present and use information; applies the retrieved information; learns, or internalizes information as a personal knowledge; presents the information product; understands ethical use of information; respects the legal use of information; and communicates the learning product with acknowledgement of intellectual property.

From the foregoing discussion, it is obvious that information literacy skills and knowledge overlapped each other. The possesion information literacy knowledge is a stepping stone to development of real skills. It can also be synthesized that information literacy skills revolves around the ability to: determine the extent of information needed; access information efficiently; critically evaluate information and its sources; classify, store, manipulate and redraft information collected or generated; use information effectively to learn, create new 
knowledge, solve problems and make decisions; access and use information ethically and legally; use information and knowledge for participative citizenship and social responsibility.

\section{Conclusion}

The review of related literature started with an exploration of the concept of information literacy, competency and information literacy competency. From these review, it is obvious that information literacy competencies could be understood as the combination of knowledge, skills and attitudes towards recognizing when and why information is needed, where to find it, how to evaluate, manage and apply, synthesize, use and communicate it ethically and legally. Three theoretical model of information literacy which include seven pillars of information literacy by SCOUNL, Big Six information literacy skills and Doyle's attribute of information literate person were also reviewed. The theories threw light on what is expected from an individual in order to attain the information literacy competencies. In other words, they dealt with attributes of information literate person which when combine with knowledge, skills and attitude will become information literacy competencies. Theoretical studies which also threw more light on information literacy knowledge and skills were also reviewed. The information literacy knowledge and skills as reviewed in the theoretical studies focuses on awareness and abilities to recognize when and why information is needed, where to find it, how to evaluate, synthesize, use and communicate it ethically and legally. Finally, based on definitions of competency as reviewed in this study, we conclude that the term Information Literacy Competency and Information Literacy skills though often used interchangeably are not the same. Information literacy competencies is a combination of knowledge, skills and attitudes towards recognizing when and why information is needed, where to find it, how to evaluate, manage and apply it, synthesize, use and communicate it ethically and legally. In order words, skill is a component of competency which includes other components (knowledge and attitude).

\section{REFERENCES}

Aina, L. O (2004). Library and information services for Africa. Ibadan: Third world information service limited
Alberta Education. (2010). Literacy first: A plan for action. Edmonton, A.B: Alberta Education. Retrieved from http://education.alberta.ca/media/ 4970645/literacyfirst.pdf

Alberta Education. (2011). Why competencies matter: What is competency. Edmonton, $\mathrm{AB}$ : Alberta education (weblog message). Retrieved on March 12, 2011 from http://myweb.lcsd150.ab.ca/groups/lakelandtechn ology department/weblog/bF71b2/

American Library Association. (1998). A progress report on information literacy: An update on the American library association presidential committee on information literacy: Final report. Chicago: American Library Association. Retrieve from http://www.ala.org/ala/acrl/acrlpubs/whitepapers/ progressreport.htm.

Andretta, S. (2005). Information literacy: A practitioner's guide. Oxford: Chandos publishing

Anttiroiko, A.-V., Lintilä, L. \& Savolainen, R. (2001). Information society competencies of managers: Conceptual considerations. In E. Pantzar, R. Savolainen \& P. Tynjälä, (Eds.), In search for a human-centred information society, (pp. 27-57). Tampere: Tampere University Press.

Association of College \& Research Libraries. (2000). Information literacy competency standards for higher education. Chicago, American Library Association. Retrieved from http://www.ala.org/ala/acrl/acrlstandards/ informationliteracycompetency.htm

Barry, C. A. (1997). Information skills for an electronic world: Raining doctoral research students. Journal of Information Science, 23 (3), $225-238$.

Bloom, B. S. (1956). Taxonomy of educational objectives: Classification of educational goals. Handbook 1: Cognitive domain. New York: Longman, Green and Co.

Boekhorst, A. K. (2003). Becoming information literate in the Netherlands.

Library Review, 52 (7), 298-309.

Bruce, C. (2004). Information literacy as a catalyst for educational change: A background paper. In Danaher, P. A., (Ed.), Proceedings "lifelong learning: Whose responsibility and what is your contribution" the $3^{\text {rd }}$ International Lifelong Learning Conference (pp. 8-19). Queensland. Retrieved from http://eprints.qut.edu.au

Bundy, A. (Ed.). (2004). Australian and New Zealand information literacy framework: Principles, standards and practice, $2^{\text {nd }}$ edition. Adelaide: Australian and New Zealand Institute for Information Literacy (ANZIIL). Retrieved from 
http://www.caul.edu.au/info-literacy/InfoLiteracy Framework.pdf

Cats, R., \& Lau, J. (2008). Towards information literacy indicators. Paris: United Nations educational, scientific and cultural organization (UNESCO). Retrieved from http://www.unesco.org/webword

Charted Institute of Library and Information Professionals. (2004). Information literacy: Definition. London: CILIP. Retrieved from http://www.cilip.org.uk /professionalguidance/informationliteracy/definit ion/

Chevillotte, S. (2007). Information Literacy state of the art report: French speaking countries: Belgium, France, Quebec, and Switzerland. In Lau, J. (Ed), Information Literacy: An International State of the Art report, (pp. 23-30). Retrieved from http://www.uv.mx/usbiver/unesco

Council of Australian University Librarians. (2001). Information literacy standards. Canberra, Council of Australian University librarians. Retrieved from http:// ilp.anu.edu.au/Infolit_standards_2001.html

DeMars, C. E., Cameron, L. \& Erwin, T. D. (2003). Information literacy as foundational: Determining competence. Journal of general education, 52 (4): 253 - 266.

Doyle, C.S. (1992). Outcome measures for information literacy within the national education goals of 1990. Final report to the National Forum on Information Literacy. Summary of findings. Syracuse NY: ERIC Clearinghouse on information resources. (Eric document ED 351033).

Eisenberg, M. B., \& Berkowitz, R. E. (1995). Information problem-solving: The big six skills approach to library and information skills instruction. Norwood, New Jersey: Ablex publishing.

Eisenberg, M.B., Lowe, C.A. \& Spitzer, K.L. (2004) Information literacy: essential skills for the information age, 2nd ed. Westport, Connecticut: Libraries Unlimited.

European Centre for the Development of Vocational Training. (2008). Terminology of European education and training policy: A selection of 100 key terms. Retrieved from http://www.cedefop.europa.eu/en/Files/4064_EN

European Commission. (2004). Key competencies for lifelong learning: A European reference framework. Retrieved from http://ec.europa.eu /education/policies/2010/doc/basicframe.pdf

European Communities. (2007). Key competencies for lifelong learning: A European reference

$\mathbf{7 8} \mid \mathrm{P}$ a g e framework. Luxembourg: European communities. Retrieved from http://ec.europa.eu/dgs/education_culture/publ/p df

Ferguson, B. (2003). Information literacy: A primer for teachers, librarians, and other informed people. Retrieved from http://www.bibliotech.us /pdfs/InfoLit.pdf

Fidzani, B. T. (2007). Information literacy state of the art report: Sub - Sahara Africa. In Lau, J. (Ed), Information Literacy: An International State of the Art Report, (pp. 86-90). Retrieved from http://www.uv.mx/usbiver/unesco http://www.uv.mx/usbiver/unesco

Fjällbrant, N. (2000). The development of web-based programs to support information literacy courses. In C. S. Bruce and P. C. Candy (Eds.), Information literacy around the world: Advances in programs and research, (pp. 27-28). Wagga Wagga, NSW: Charles Sturt University.

Grassian, E. S., \& Kaplowitz, J. R. (2001). Information literacy instruction: Theory and practice. New York: Neal-schuman.

Homann, B. (2001). Difficulties and new approaches in user education in Germany. Proceedings of the 67th IFLA council and general conference, (pp. 16-25). Hague: International Federation of Library Associations. Retrieved from http://www.ifla.org/IV/ifla67/papers/072126e.pdf

Horton, F.W. (2007). Understanding information literacy: A primer. Paris: United Nations Educational, Scientific and Cultural Organization (UNESCO). Retrieved from http://www.unesco.org/webword

Information Literacy Meeting of Experts. (2003). The Prague declaration: Towards an information literate society. National Commission on Library and Information Science; National Forum on Information Literacy \& UNESCO. Retrieved from

http://www.nclis.gov/libinter/infolitconf\&meet/p ost-infolitconf\&meet/post-infolitconf\&meet.html

Jacobs, S., Rosenfeld, P. \& Harber, J. (2003). Information literacy as the foundation for evidence based practice in graduate nursing education: A curriculum integrated approach. Journal of Professional Nursing, 19(5), 320-328. Retrieved from http://www.professionalnursing.org/article/s8755 -7223(03)0097-8/abstract

Johnston, B., \& Webber, S. (2003). Information literacy in higher education: A review and case study. Studies in Higher Education, 28(3), 335352. 
Kaushik, P. S., \& Mishra, S. (2009). Necessity of information literacy in higher education in India. International Conference of Knowledge Networking in ICT Era, (pp. 108-114). Retrieved from http://portal.unesco.org/ci/en/files /28265/12341778449.special_session _presentations.pdf

King, L. (2007). Information literacy of incoming undergraduate arts students at the University of the Western Cape. (Doctoral dissertation, University of the Western Cape). Retrieved from http://etd.uwc.ac.za/usrfiles/modules/etd/docs/etd _gen8Srv25Nme4_4797_12169920995.pdf

Kovalik, C. L., Jensen, M. L., Schloman \& Tipton, M. (2010). Information literacy collaboration, and teacher education. Communication and Information Literacy, 4,145-169. Retrieved from http://www.comminfolit.org/index.php

Langford, L. (1998). Information literacy: A clarification. School Libraries Worldwide, 4 (1), 59-72.

Lau, J. (2006). Guidelines on information literacy for lifelong learning. Retrieved from http://www.ifla.org/files/informationliteracy/publications/ifla-guidelines-en.pdf

Losee, R. M. (1997). A discipline independent definition of information. Journal of the American Society for Information Science, 48 (3) (1997): 254-269.

Middle States Commission on Higher Education. (2003). Developing research and communication skills: Guidelines for information literacy in the curriculum. Philadelphia: Middle states commission on higher education. Retrieved from http://www.msche.org/publications/developingskills080111151714.pdf

Mitchell, E. (n.d.). Information literacy: Theoretical foundation. Retrieved on February 12, 2012 from http://erikmitchel.info/uploaded_files/dissertation /1_information_literacy_mitchel.pdf

Mittermeyer, D., \& Quirion, D. (2003). Information literacy study of incoming first-year undergraduates in Quebec. Canada: Quebec Universities.

Nayda, R., \& Rankin, E. (2008). Information literacy skill development and lifelong learning: Exploring nursing students' and academics' understanding. Australian Journal of Advanced Nursing, 26 (2), 27-33. Retrieved from http://www.ajan.com.au/vol26/26-2.pdf

Neely, T. Y. (2002). Sociological and psychological aspects of information literacy in higher education. Lanham, Maryland: Scarecrow.

Newto, A. (2005). What is information literacy? Retrieved from http://www.ldu. leeds.ac.uk/news/events/documents/informationli teracy.pdf

Ojedokun, A. A. (2007). Information literacy for tertiary education students in Africa. Ibadan: Third world information services limited.

Ojedokun, A. A. (2011). Information literacy: Models, standards and strategies. Paper presented in Library and Information Technology Today (LITT) workshop held at the Ogwasi-uku Polytechnic, Delta state.

Omekwu, C. O. (2003). Information technology revolution, libraries and cultural values: Issues, impacts and inevitable challenges for Africa. Word Library and Information Congress: $6^{\text {th }}$ IFLA General Conference and Council. Retrieved from http://www.ifla.org

Organization for Economic Co-opreation and Development. (1999). Definition and selection of competence: Concepts of competence. Retrieved from

http://citeseerx.ist.psu.edu.edu/view/download\% 3Fdoi\%3D10.1.1.111.1152\%26rep\%3Drep1\%26 type $\% 3 \mathrm{Dpdf}$

Organization for Economic Co-operation and Development. (2005). DeSeCo project: The definition and selection of key competencies: Executive summary. Retrieved from http://www.oecd.org/dataoecd/47/61/ 35070367.pdf

Owusu-Ansah, E.K. (2003). "Information literacy and the academic library: a critical look at a concept and the controversies surrounding it". The Journal of Academic Librarianship, 29 (4), 219230. Retrieved from http://www.sciencedirect.com

Pinto, M., \& Sales, D. (2006). Information literacy state of the art report: Spain. In Lau, J. (Ed.), Information Literacy: An International State of the Art Report, (pp. 54-85). Retrieved from http://www.uv.mx/usbiver/unesco

Ranaweera, P. (2008). Importance of information literacy skills for an information literate society. In proceedings NACLIS. Retrieved from http://eprints.rclis.org /archive/00014146/

Ranaweera, P. (2010). Information literacy programmes conducted by the universities in Sri Lanka. Journal of the University Librarians Association of Sri Lanka, 14(1), 61-75. Retrieved from images/pdf/prelimina.pdf http://www.ulasl.org/

Regha, V. S., Rani, B. S. \& Hariharan, A. (2009). Information literacy education for higher educational institutions in India. International Conference of Knowledge Networking in ICT Era, (pp. 115-125). Retrieved from 
http://portal.unesco.org/ci/en/files/28265

/12341778449.special_session_presentations.pdf

Rekha, V. S. (2009). Information literacy education for higher education institution in India. International Conference of Knowledge Networking in ICT Era, (pp. 55-75). Retrieved from

http://portal.unesco.org/ci/en/files/28265/123417 78449. special_session_present ati ons.pdf

SCONUL. (2011). The SCONUL seven pillars of information literacy. A research lens for higher education. SCONUL working group of information literacy. Retrieved from http://www.sconul.ac.uk/groups/information_lite racy /seven_pillars.html

Shenton, A. K. (2009). Information literacy and scholarly investigation: A British perspective. Journal of the International Federation of Library Associations and Institutions, 35(3), 209291. Retrieved from http://ifl.sagepub.com

Sinikara, K. \& Järveläinen, L. (2003). Information literacy development in Finland. Library Review, 52(7), 333-339. Retrieved from http://www.ifla.org /files/informationliteracy/publications/il-report/nordic-countries2006.pdf

Thomas, N. P. (2004). Information literacy and information skills instruction: Applying research to practice in the school library media centre, $2^{\text {nd }}$ ed. London: Libraries unlimited.

Tolonen, E. (2006). Information Literacy state of the art report: Nordic countries: Finland, Denmark, Norway and Sweden. In Lau, J. (Ed.), Information Literacy: An International State of the Art Report, (pp. 48-53). Retrieved from http://www.uv.mx/usbiver/unesco

Town, J. S. (2002). Information literacy: Definition, measurement \& impact. Paper presented at the International conference on IT and information literacy. Abstract retrieved from http://www.iteu.gla.ac.uk/elit/itilit2002 /papers/ab15.html

University of Calgary Library. (n.d.). Information: Definitions and competencies. Retrieved from http://www.ucalgary.ca/libold/ILG/workdef.html

Virkus, S. (2003). Information literacy in Europe: A literature review. Information Research 8(4), 159. Retrieved from http://informationr.net/ir/84/paper159 .html

Virkus, S., Boekhorst, A. K., GomezHernandezJ.A., Skov, A. \& Webber, S. (2005). Information literacy and learning. In Kajberg, L. and Lørring, L. (Eds.) European Curriculum: Reflections on Library and Information Science Education, (pp. 6583). Copenhagen: The Royal School of Library and Information Science. Retrieved from http://biblis.db.dk/uhtbin/ hyperion.exe/db.leikaj05

Webb, J., \& Powis, C. (2005). Start with the learner. Library and Information Update, 4 (1-2), 50-52.

Webber, S. (2006). Information literacy standards and statements. Retrieved from http://dis.shef.ac.uk/literacy/standards.htm

Wen, J. R., \& Shih, W. L. (2008). Exploring the information literacy competence standards for elementary and high school teachers. Computers \& Education, 50, 787-806 Taiwan: Elservier, LTD. Retrieved from: http://www.elservier. com/locate/compedu

Wilson, L. A. (2001). Information literacy: fluency across and beyond the university. In B. I. Dewey (Ed.), Library User Education: Powerful learning, powerful partnership, (pp. 1-17). Lanham, MD: Scarecrow Press, Inc

Zinc, C. (2007). Conceptual approaches for defining data, information and knowledge. Journal of the American society for information science and technology, $158 \quad$ (4), 479-495, DOI:10.1002/asi.20508 